УДК 39:930

DOI: $10.17223 / 19988613 / 68 / 17$

\title{
Н.А. Томилов
}

\section{ЭТНОГРАФИЯ ТЮРКСКИХ НАРОДОВ В ТРУДАХ СИБИРЕВЕДОВ (К ИТОГАМ 50-ЛЕТНИХ ИССЛЕДОВАНИЙ)}

\author{
Статья представляет расширенный вариант доклада, прочитанного на юбилейной XVIII Международной Западносибирской \\ археолого-этнографической конференции «Западная Сибирь в транскультурном пространстве Северной Евразии: итоги \\ и перспективы 50 лет исследований ЗСАЭК», состоявшейся 16-18 декабря 2020 г. на базе Томского государственного \\ университета.
}

\begin{abstract}
Статья нацелена на разработку периодизации истории исследований этнографии тюркских народов сибирскими учеными, главным образом томского и омского научных центров, с конца 1960-х гг. по настоящее время, а также на раскрытие основной тематики данного направления. Исследование основано на трудах ученых по этнографии тюркских народов Сибири, информационных статьях о научных форумах, экспедициях и о самих ученых-тюрковедах. Проведен обобщенный историографический анализ трудов сибирских этнографов по изучению тюркских народов региона, результаты которых востребованы в различных сферах деятельности общества. Ключевые слова: этнография; тюркские народы; периодизация; история науки.
\end{abstract}

Значимость тематики статьи определяется тем, что тюркские народы в Сибири образуют после славянских народов также значительный массив населения со своеобразной этнической историей, существенным культурным наследием и, соответственно, значимым вкладом в формирование и развитие исторической общности россиян. Основное внимание в данной статье уделено исследованиям по этнографии тюркских народов Сибири ученых томского и омского научных центров, которые целенаправленно и систематически стали проводить Томский государственный университет (ТГУ) с конца 1960-х гг. и затем с середины 1970-х гг. Омский государственный университет (ОмГУ). Ставятся задачи разработать периодизацию истории этих исследований на протяжении последних 50 лет и осветить организацию и основную тематику научных работ томских, омских и частично ученых других регионов Западной Сибири, кроме ученых учреждений автономных республик Южной Сибири. Основными источниками данного исследования являются научные труды ученых-сибиреведов по этнографии тюркских народов Сибири, информационные статьи о научных форумах, экспедициях и о самих ученых-тюрковедах. Методические подходы к выполнению заявленной темы связаны с историографической наукой, в которой у нас имеется определенный опыт исследований, получивший положительную оценку со стороны историографов В.П. Корзун и М.А. Мамонтовой $[1,2]$.

В изучении этнографии тюркских народов Сибири томскими и омскими учеными в последние полвека видятся три периода: первый - это конец 1960-х - первая половина 1970-х гг. - развертывание исследований силами ученых ТГУ в основном среди татар Западной Сибири и чулымскх тюрков; второй - середина 1970-х 1980-е гг. - наряду с работами томских ученых развитие масштабных этнографических исследований группой ученых ОмГУ, а также антропологических работ этими двумя университетами - изучение этнографии алтайцев, бачатских телеутов, казахов, татар, хакасов, чувашей, чулымских тюрков, шорцев, а, кроме того, поздних археологических памятников тюркских групп учеными Новосибирска; третий - с 1990-х гг. по настоящее время - расширение и углубление до фундаментального уровня этнографических работ томских и омских ученых, в том числе за счет присоединения к этим работам ученых Омского филиала Объединенного института истории, филологии и философии (ОИИФФ) СО РАН (с 2006 г. - Омский филиал Института археологии и этнографии (ИАЭТ) СО РАН, а с 2018 г. Омская лаборатория археологии, этнографии и музееведения ИАЭТ СО РАН), а также проведение этнографических исследований учеными Барнаула, Кемерова, Новосибирска, Тобольска, Тюмени.

Рассмотрение первого периода в изучении этнографии, отчасти археологии, антропологии и языкознания тюркских народов Сибири следует, видимо, начать с указания на то, что в Томске такие исследования проводились и ранее, во всяком случае со времени изысканий Г.Н. Потанина. В середине и начале третьей четверти ХX в. были опубликованы работы историков Н.Ф. Емельянова, В.С. Синяева, историка и археолога З.Я Бояршиновой, археологов В.И. Матющенко, Е.М. Пеняева, Л.М. Плетнёвой и др., антропологов В.А. Дрёмова, Н.С. Розова, лингвистов А.П. Дульзона, М.А. Абдрахманова, А.А. Бонюкова, О.И. Гордеевой, этнографов Н.В. Лукиной, Г.И. Пелих (работа о «карагасах» Томской области). Их вклад в изучение истории и культуры сибирских татар, чулымских тюрков, шорцев и некоторых других тюркских народов Сибири изучен и нашел отражение в ряде работ [3. С. 6-20; 4; 5. С. 10-23; 6. С. 15-24 и др.]. Наличие такого задела работ названных направлений стимулировало дальнейшее изучение этнографии ряда тюркских народов. 
В 1968 г. в ТГУ была открыта Проблемная научноисследовательская лаборатория истории, археологии и этнографии Сибири (ПНИЛИАЭС). Двое из группы этнографов, а именно Н.А. Томилов и М.С. Усманова, стали заниматься этнографией тюркских народов, так же как и работавшая на историческом факультете Э.Л. Львова. Были определены и темы для выполнения кандидатских диссертаций: Э.Л. Львовой - «Чулымские тюрки (историко-этнографические очерки)», Н.А. Томилову - «Современные этнические, культурные и бытовые процессы среди сибирских татар», и позднее М.Л. Усмановой - «Дохристианские верования хакасов в конце XIX - начале XX века».

С 1969 г. начался этап создания источниковой базы для выполнения намеченных исследований. В 1969 г. состоялись две экспедиции ТГУ - среди чулымских тюрков (руководитель Э.Л. Львова, среди участников был и Н.А. Томилов) и среди томских татар (руководитель Н.А Томилов). Экспедиции к чулымским тюркам происходили затем ежегодно вплоть по 1975 г., и к томским, барабинским и тоболо-иртышским татарам в этот период - также ежегодно вплоть по 1974 г. В числе основных задач в развитии этнографических исследований ТГУ была подготовка кадров ученых данного профиля, которая осуществлялась, прежде всего, посредством работы над кандидатскими диссертациями. В 1971 г. Н.А. Томилов прошел годичную стажировку в Институте этнографии им. Н.Н. МиклухоМаклая АН СССР в Москве. Э.Л. Львова и Н.А. Томилов также осуществляли руководство ежегодными этнографическими практиками студентов и руководство курсовыми и дипломными работами по этнографии на историческом факультете ОмГУ.

Укреплению научных навыков в работе с этнографическими материалами способствовало участие в научной паспортизации и каталогизации этнографических предметов Музея археологии и этнографии Сибири (МАЭС) ТГУ. Научно паспортизированы были и предметы культуры ряда тюркских народов - алтайцев, долган, казахов, киргизов, татар, тувинцев, узбеков, уйгуров, хакасов, чулымских тюрков, шорцев и якутов. Это был уникальный для советской науки опыт работы с этнографическими музейными предметами, начавшийся в 1969 г. и закончившийся изданием в 1979-1980 гг. каталога этнографических коллекций МАЭС ТГУ в двух частях [7]. Его авторами были П.Е. Бардина, В.М. Кулемзин, Н.В. Лукина, Э.Л. Львова, А.М. Сагалаев, Н.А. Томилов, М.С. Усманова, геолог Д.П. Славнин, а большая часть иллюстраций была выполнена В.Б. Богомоловым. Последний увлекся изучением орнамента и в 1973 г. опубликовал свою первую статью об орнаменте барабинских и томских татар. Появились и первые кандидаты наук среди этнографов, занятых тюркской тематикой. В 1973 г. в Москве защитил диссертацию Н.А. Томилов.

Подготовке специалистов-этнографов способствовало участие томичей в научных форумах. Первый доклад о работах по этнографии тюркских народов был сделан Э.Л. Львовой в соавторстве с Н.А. Томиловым в Новосибирске 1 декабря 1971 г. на зональном археолого-этнографическом совещании. На следующий год в ТГУ прошло Второе Западно-Сибирское совещание археологов и этнографов, которое стало регулярным проводится раз в три года в статусе конференции. В Томске же раз в несколько лет проходили всесоюзные научные конференции «Происхождение аборигенов Сибири и их языков». Томские этнографы в этот период занялись подготовкой и изданием сборников научных трудов. Три сборника из серии «Из истории Сибири» были изданы как археолого-этнографические с участием антропологов - в 1969, 1975 и 1976 гг., а один сборник - 1972 г. - состоял целиком из этнографических статей и назывался «Материалы по этнографии Сибири» [8]. Среди авторов статей помимо томичей были бывшие омичи, переехавшие в Казань, - этнограф и историк Ф.Т.-А. Валеев и языковед С.М. Исхакова, которые влились в работу групп сибирских ученых, исследующих этнографию татар Западной Сибири. Заметным событием тех лет была защита в 1970 г. барнаульским археологом и историком А.П. Уманским кандидатской диссертации, освещающей историю и частично этнографию телеутов. В 1970-е гг. в Новосибирске успешно работала Е.М. Тощакова по изучению культуры алтайцев.

Второй период, расширяющий поле этнографического изучения тюркских народов сибирскими учеными, связан с тем, что наряду с томским этнографическим центром возникла и стала проводить целенаправленные исследования группа омских этнографов, сосредоточившихся в открытом в 1974 г ОмГУ. Уже в первый год существования ОмГУ переехавшие из Томска В.Б. Богомолов и Н.А. Томилов провели первую этнографическую экспедицию к тарским татарам, вместе с участниками вновь созданного этнографического студенческого кружка создали первую экспозицию образованного в ноябре 1974 г. Музея археологии и этнографии ОмГУ, приступили к работе по научной паспортизации и каталогизации этнографических коллекций Омского областного краеведческого музея, позднее ведущих музеев Новосибирска и Тюмени. В результате этих работ стала издаваться научная серия «Культура народов мира в этнографических собраниях российских музеев», первые два тома которой увидели свет в 1986 и 1990 гг. [10. С. 137-139], а всего на сегодняшний день в этой серии издано более 20 томов.

Экспедиции проводились ежегодно к разным народам и национальным группам в основном Западной и частично Восточной Сибири, а также Северного Казахстана и Поволжья. Среди тюркских народов исследованиями были охвачены алтайцы, астраханские, казанские татары и мишари, бачатские телеуты, казахи, сибирские татары, тофалары, тувинцы, хакасы, чуваши, чулымские тюрки и шорцы [9. С. 135-148].

И в Томске, и в Омске во второй половине 19701980-х гг. формировались и успешно работали группы занимающихся этнографией тюркских народов ученых. Отметим, что все эти прошедшие десятилетия между томскими и омскими этнографами сохранялось плодотворное сотрудничество, как это имеет место и сегодня. Рос и профессиональный уровень членов этих групп. Кандидатские диссертации защитили в те годы Э.Л. Львова (1978) и М.С. Усманова (1989) по назван- 
ным выше темам, а также А.М. Сагалаев на тему «Ламаистские элементы в мифологии и традиционных культах алтайцев» (1981), Л.И. Шерстова на тему «Алтай-кижи в конце XIX - начале XX века» (1986).

В 1985 г. в ОмГУ была открыта кафедра этнографии - третья в РСФСР после кафедр Ленинградского и Московского государственных университетов. Соответственно, возникла система спецкурсов и спецсеминаров по этнографии. Коллектив этнографов с высшим образованием состоял в ОмГУ из преподавателей кафедры и работавших по хоздоговорным темам научных сотрудников и старших лаборантов - всего более 10 человек.

Повышался и профессиональный уровень омских этнографов. В 1983 г. Н.А. Томилов защитил докторскую диссертацию «Этническая история тюркоязычного населения Западно-Сибирской равнины в конце XVI - начале XX вв.», а его казанский единомышленник Ф.Т.-А. Валеев в 1987 г. - также докторскую диссертацию «Сибирские татары (проблемы этнокультурного развития во второй половине XIX - начале XX вв.)»; в 1986 г. О.М. Проваторова защитила кандидатскую диссертацию «Современные этнические процессы у казахов Западной Сибири». В коллектив омских этнографов вошла и одна из основателей современной казахстанской этнографии кандидат наук И.В. Захарова, работавшая до этого в Омском государственном педагогическом институте. С этим коллективом работал и хакасский этнограф В.П. Кривоногов, который в 1984 г. защитил кандидатскую диссертацию «Современные этнические процессы среди хакасов». В этот же период защитили кандидатские диссертации тесно сотрудничавшие с омскими этнографами кемеровский этнограф В.М. Кимеев на тему «Шорский этнос. Основные этапы формирования и этническая история (XVIII-XX вв.)» (1986) и новосибирский археолог В.И. Соболев на тему «Барабинские татары XIV начала XVII вв. н.э. (по археологическим материалам)» (1983). Регулярное и плодотворное сотрудничество у этнографов установилось с омскими археологами доктором наук В.И. Матющенко и Б.А. Кониковым, защитившем в 1982 г. кандидатскую диссертацию «Культуры таежного Прииртышья VI-XIII вв. н.э.».

С целью обсуждения научных проблем, изучением которых занимаются омские и томские этнографы, а с ними и специалисты других смежных наук, в этот период увеличилось количество проводимых научных форумов. Возрастали авторитет и значимость Западносибирских археолого-этнографических совещаний. В Омске начиная с 1976 г. научные конференции по археологической, этнографической и этносоциологической тематике стали проводиться ежегодно - сначала как региональные (сибирские), позднее как всесоюзные. Наиболее значимыми были следующие всесоюзные научные конференции: «Этногенез и этническая история тюркского населения Сибири и сопредельных территорий» (1979), «Этническая история тюркских народов Сибири и сопредельных территорий» (1984), «Социально-культурные процессы в советской Сибири» (1985), «Этнографическая наука и пропаганда этнографических знаний» (1987).
В издательской деятельности сибирских этнографов прогресс также был очевиден: наряду с большим количеством сборников научных трудов стали издаваться монографии. Новосибирскими и томскими коллегами было подготовлено и увидело свет в 19881990 гг. трехтомное фундаментальное монографическое издание «Традиционное мировоззрение тюрков Южной Сибири». Авторами монографий стали Э.Л. Львова, И.В. Октябрьская, А.М. Сагалаев, М.С. Усманова. В этот же период было издано несколько книг Н.А. Томилова - «Современные этнические процессы среди сибирских татар» (1978), «Этнография тюркоязычного населения Томского Приобья (хозяйство и материальная культура)» (1980) «Тюркоязычное население Западно-Сибирской равнины в конце XVI - первой половине XIX вв.» (1981), «Очерки этнографии тюркского населения Томского Приобья (этническая история, быт, духовная культура» (1983) и др.

Начавшийся в 1990-е гг. и продолжающийся последние 30 лет третий период характеризуется настолько обширными и существенными показателями в дисциплинарной организованности научного сообщества, кадровом составе сибирских ученыхтюрковедов, консолидирующей роли томского и омского научных центров в российской научной сфере деятельности тюрковедов, достижении значимых результатов исследований в нескольких субдисциплинах и научных направлениях этнографии и смежных с нею наук, что в кратком обзоре их трудно охватить. Тем более что пока за пределами данного обзора остаются работы наших коллег, работавших в учреждениях автономных областей Сибири (Н.А. Алексеев, С.М. Биче-Оол, В.Я. Бутанаев, М.В. Монгуш, Н.А. Тадина, Н.И. Шатинова и др.). Поэтому здесь о третьем периоде - в самом тезисном виде.

Выше уже шла речь о том, что в Омске в 1991 г. было создано учреждение СО РАН по археологии, этнографии и музееведению. В 1993 г. в этом же городе возникло еще одно научное учреждение - Сибирский филиал Российского института культурологии; c 2014 г. это Сибирский филиал Российского научноисследовательского института культурного и природного наследия им. Д.С. Лихачева. В нем также работает группа этнографов, в том числе есть и тюрковеды. В ОмГУ по-прежнему функционирует кафедра с этнографическим направлением. В Омском государственном педагогическом университете около 70 лет работает Сибирский региональный вузовский центр по фольклору (руководитель - доктор филологических наук Т.Г. Леонова, которая занимается в том числе и этнографическими сюжетами), организующий проведение в Омске ежегодного Сибирского научнопрактического семинара «Народная культура Сибири». Много этнографов трудятся и в омских музеях. Сегодня в Омске по профилю работает около 50 этнографов, а многие выходцы из омского этнографического центра работают в других городах России - от Москвы и Санкт-Петербурга до Анадыря, а также в Германии, Казахстане и Канаде [11].

В Томске в ТГУ и Томском государственном педагогическом университете имеются кафедры с этногра- 
фическим компонентом в названии. По-прежнему функционирует вышеупомянутая проблемная лаборатория ТГУ - ПНИЛИАЭС.

Существенные сдвиги происходили и в кадровом составе сибирских ученых, занятых тюркской тематикой. Докторские диссертации были защищены по отечественной истории - Л.И. Шерстова «Этнополитическая история тюрков Южной Сибири. XVII - начало ХХ вв.» (1999), по этнографии - А.М. Сагалаев «Архаичное мировоззрение урало-алтайских народов Западной Сибири» (1992), В.П. Кривоногов «Современные этнические процессы у малочисленных коренных народов Средней Сибири» (2000), И.В. Октябрьская «Казахи Алтая: этнополитические и социокультурные процессы в пограничных районах Южной Сибири XIV-XX вв.» (2004), В.М. Кимеев «Этномузеи Притомья и сохранение этнокультурного наследия: генезис, архитектоника, функции» (2009), Д.Г. Коровушкин «Диаспоры Западной Сибири: особенности этнокультурного развития сельских сообществ в конце XIX - начале XXI в.» (2009), по археологии: В.И. Соболев «История сибирских ханств (по археологическим материалам)» (1994), по антропологии - А.Н. Багашёв «Формирование древнего и современного населения Западной Сибири по данным краниологии» (2000), по филологии - Х.Ч. Алишина «Историко-лингвистическое исследование ономастикона сибирских татар (на материале Тюменской области)» (1999) и Ф.Х. Гильфанова «Этнолингвистическое исследование антропонимии тарских и барабинских татар (на материале русских архивных документов XIX-XX вв.)» (2007).

B Томске успешно работает диссертационный совет по защите диссертаций на соискание ученой степени доктора исторических наук при ТГУ. В нем защитили кандидатские диссертации томские этнографы-тюрковеды: по этнографии шорцев - Л.С. Борина (2003), по этническому составу населения Нижнего Притомья - Т.А. Гончарова (2004), по этнографии хакасов - Г.В. Грошева (2008), по этнографии татар Томской области - И.Г. Поправко (2010).

Омские этнографы защищали кандидатские диссертации в разных городах - Алма-Ате, Кемерово, Москве, Санкт-Петербурге, Томске, но больше всего в Новосибирске и Омске. Защитили диссертации по этнографии разных групп татар Западной Сибири А.Г. Селезнев (1991), Н.В. Кулешова (1995), С.Н. Корусенко (1996), Н.А. Левочкина и Е.Ю. Смирнова (1998), Ф.Х. Гильфанова и М.А. Корусенко (1999), И.А. Селезнева (2000), Ф.М. Фаткулина (2001), Л.М. Кадырова, О.П. Коломиец и А.А. Ярзуткина (2004), М.Н. Тихомирова (2005), Е.В. Титов (2008), Д.М. Лукманова и Д.А. Мягков (2009), А.А. Ильина (2010), A.М. Диянова (2012), по этнографии казахов, татар и русских - А.В. Матвеев (2003), по истории и этнографии казахов - 3.Е. Кабульдинов (1997), Ш.К. Ахметова (2001), Б.К. Смагулов (2002), А.С. Сарсамбекова и А.В. Смелякова (2009), А.А. Дайрабаева (2010), по этнографии алтайцев - Е.А. Бельгибаев (2001), И.И. Назаров (2004), по этнографии шорцев - Г.М. Патрушева (1992), по этнографии чувашей - Д.Г. Коровушкин (1991).
Среди ученых из других городов, работающих по тюркской тематике и защитивших кандидатские диссертации, - 3.А. Тычинских из Тобольска с диссертацией по этнографии сибирских татар (2007); в 2008 г. защитила диссертацию Е.В. Самушкина из Новосибирска на тему о этнополитическом движении в республиках Алтай, Тыва и Хакасия (2008).

В 1991 г. кандидатскую диссертацию по этнографии бачатских телеутов защитил в Ленинграде работавший тогда в Омске Д.А. Функ, который уже как московский этнограф в 2003 г. защитил докторскую диссертацию «Шаманская и эпическая традиция тюрков юга Западной Сибири». Отметим, что Д.А. Функ и Н.А. Томилов были составителями и редакторами фундаментального тома «Тюркские народы Сибири», вышедшего в 2006 г. в серии «Народы и культуры» [12]. Нужно также отметить ученых, которые не защищали диссертации, но внесли значительный вклад в тюрковедение, и прежде всего это омские этнографы Э.Р. Ахунова, В.Б. Богомолов, В.В. Мерзликин, Р.Ф. Уразалеев, Л.Т. Шаргородский, тобольский историк и этнограф И.В. Белич.

И в Томске, и в Омске в этот период почти ежегодно проходили научные форумы с этнографической составляющей. Регулярный статус принял международный научный симпозиум «Интеграция археологических и этнографических исследований», который омичи с 1993 г. провели 22 раза в городах России, а также в Казахстане и на Украине. В 2011 г. в Омске прошел Международный научный конгресс «Этническая история и культура тюркских народов Евразии».

Издательская деятельность сибирских тюрковедов характеризуется высокой активностью. Это десятки монографий, сотни сборников статей и материалов научных форумов. Фундаментально значимыми стали научные серии, и среди них изданные томичами в 1994-1998 гг. в пяти книгах «Очерки культурогенеза народов Западной Сибири» и омская научная серия «Этнографо-археологические комплексы: проблемы культуры и социума», в которой в 1996-2016 гг. было опубликовано 14 томов.

Тематическая направленность исследований сибирских ученых-тюрковедов достаточно разнообразна. Они получили значимые научные результаты в таких субдисциплинах и направлениях этнографии, как теория и история этнографических исследований с историографической оставляющей, этническая история, современные этнические процессы, культурно-генетические и культурно-динамические исследования, этноархеология, этногенеалогия, этнополитология, этносоциология, этнографическое религиоведение, этнографическое музееведение, этнохореография. Результаты исследований сибирских этнографов в российском обществе были использованы в практике управления культурными, социальными и политическими процессами, формирования мировоззрения россиян, проведения образовательной и просветительной работы. Но характеристика этих научных исследований и их использования для стабильного развития российского общества - это темы для специальных историографических и историко-научных очерков. 


\section{ЛИТЕРАТУРА}

1. Корзун В.П. Опыты историко-научных исследований в творчестве Н.А. Томилова // Этнограф, культуролог, историк... : к 70-летию профессора Николая Аркадьевича Томилова. Омск : Наука, 2011. С. 221-226.

2. Корзун В.П., Мамонтова М.А. «Стихийные этнографы» в региональном интеллектуальном ландшафте: В.И. Матющенко, Н.А. Томилов // Вестник Томского государственного университета. 2018. № 436. С. 151-158.

3. Емельянов Н.Ф. Население Среднего Приобья в феодальную эпоху (состав, занятия и повинности) / отв. ред. В.И. Матющенко, Н.А. Томилов. Томск : Изд-во Том. ун-та, 1980. 252 с.

4. Жеравина А.Н. Жизненный и творческий путь 3.Я. Бояршиновой // Человек в истории : памяти профессора 3.Я. Бояршиновой. Томск : Изд-во Том. ун-та, 1999. С. 3-12.

5. Томилов Н.А. Этническая история тюркоязычного населения Западно-Сибирской равнины в конце XVI - начале XX вв. / отв. ред. В.И. Васильев, Р.С. Васильевский. Новосибирск : Изд-во Новосиб. ун-та, 1992. 271 с.

6. Львова Э.Л., Дремов В.А., Аксянова Г.А. и др.Тюрки таежного Причулымья. Популяция и этнос / под ред. В.П. Алексеева. Томск : Изд-во Том. ун-та, 1991. 246 с.

7. Каталог этнографических коллекций Музея археологии и этнографии Сибири Томского университета / отв. ред. Н.А. Томилов. Томск : Изд-во Том. ун-та, 1979. Ч. I: Народы Сибири. 343 с.; 1980. Ч. II: Народы СССР (кроме Сибири) и зарубежных стран. 252 с.

8. Материалы по этнографии Сибири / отв. ред. Н.В. Лукина, Н.А. Томилов. Томск : Изд-во Том. ун-та, 1972.168 с.

9. Захарова И.В., Томилов Н.А. Этнографические научные центры Западной Сибири середины XIX - начала XXI века. Омский этнографический центр / отв. ред. В.П. Корзун, В.И. Матющенко. Омск : Наука, 2007. 400 с.

10. Томилов Н.А. Томский и омский опыт научной каталогизации этнографических фондов сибирских музеев // Приобье глазами археологов и этнографов. Томск : Изд-во Том. ун-та, 1999. С. 134-139.

11. Смирнова Т.Б. Омская школа этнографии // Этнография. 2019. № 4. С. 181-194.

12. Тюркские народы Сибири / отв. ред. Д.А. Функ, Н.А. Томилов. М. : Наука, 2006. 678 с.

Nikolay A. Tomilov, Institute of Archeology and Ethnography of the Siberian Branch of the Russian Academy of Sciences, Omsk Laboratory of Archeology, Ethnography and Museology (Omsk, Russian Federation). E-mail: n.a.tomilov@ gmail.com

THE TURKIC PEOPLES ETHNOGRAPHY IN THE WORKS OF SIBERIA RESEARCHERS (TO THE RESULTS OF 50 YEARS OF STUDIES)

Keywords: ethnography, the Turkic peoples, periodization, scientific history.

The aim of the scientific paper is to research the history of ethnographic studies of Turkic peoples that has been produced for recent 50 years by the scholars of Tomsk and Omsk scientific centres and also by scholars from other Siberian cities. The result of using of historiographical approach to the subject is a creation of the periodization of the studies history with special attention at the activity of the institutions, which carry out such researches, accordingly, the composition of the staff of scientists, on the disciplinary organization of the community of Siberian turkologists, and the results of their investigations in Siberian Turkic peoples ethnography.

In the presented paper such written sources as Siberian ethnographers published papers, articles on the activity of the scientific establishments and articles by scholars, who study the Turkic peoples ethnography, and also scientific forums on Turkic topics, were used: Three periods were defined in the Tomsk and Omsk scholars ethnographic studies. The first period is the end of the 1960s to the first half of the 1970s. It is characterized by founding of the Tomsk ethnographic centre, where archaeologists and ethnographers were laboring, especially ones who studied Siberian Tatars and Chulym Turks. The second period is mid 1970s - 1980s. It is connected with a formation of the Omsk ethnographic centre and collaborative work of Omsk and Tomsk centres on the study of ethnography and anthropology of Altaians, Bachat Teleuts, Kazakhs, Tatars, Khakas, Chuvashes, Chulym Turks and Shorians. The third period has started in the 1990s and goes on nowadays. It may be characterized by expansion of researches in the field of ethnography and ethnoarchaeology of the Turkic peoples produced by scientists from Omsk and Tomsk with the involvement of specialists from other cities centres. In this period a great number of fundamental scientific series was published, like "Essays on cultural genesis of the Western Siberian peoples" (Ocherki kulturogenesa narodov Zapadnoy Sibiri)? "Ethnographic and archaeological complexes: the problems of culture and society" (Etnograficheskie kompleksi: problem kulturi I sotsiuma), "Integration of archaeological and ethnographic researches" (Integraciya arkheologicheskikh I etnographicheskikh issledoavniy).

\section{REFERENCES}

1. Korzun, V.P. (2011) Opyty istoriko-nauchnykh issledovaniy v tvorchestve N.A. Tomilova [Experiments in historical and scientific research in the work by N.A. Tomilov]. In: Remnev, A.V. \& Strunin, V.I. (eds) Etnograf, kul'turolog, istorik... K 70-letiyu professora Nikolaya Arkad'evicha Tomilova [Ethnographer, culturologist, historian ... To the 70th anniversary of Professor Nikolai Arkadievich Tomilov]. Omsk: Nauka. pp. 221-226.

2. Korzun, V.P. \& Mamontova, M.A. (2018) "Spontaneous ethnographers" in the regional intellectual landscape: V.I. Matyushchenko, N.A. Tomilov. Vestnik Tomskogo gosudarstvennogo universiteta - Tomsk State University Journal. 436. pp. 151-158. (In Russian). DOI: $10.17223 / 15617793 / 436 / 18$

3. Emelyanov, N.F. (1980) Naselenie Srednego Priob'ya vfeodal'nuyu epokhu (sostav, zanyatiya i povinnosti) [Population of the Middle Ob region in the feudal era (composition, occupation and duties)]. Tomsk: Tomsk State University.

4. Zheravina, A.N. (1999) Zhiznennyy i tvorcheskiy put' Z.Ya. Boyarshinovoy [Z.Ya. Boyarshinova: life and creativity]. In: Zheravina, A.N. (ed.) Chelovek v istorii: pamyati professora Z.Ya. Boyarshinovoy [Person in History. In Memory of Professor Z. Ya. Boyarshinova]. Tomsk: Tomsk State University. pp. 3-12.

5. Tomilov, N.A. (1992) Etnicheskaya istoriya tyurkoyazychnogo naseleniya Zapadno-Sibirskoy ravniny v kontse XVI-nachale XX vv. [Ethnic history of the Turkic-speaking population of the West Siberian Plain in the late 16th - early 20th centuries]. Novosibirsk: Novosibirsk State University.

6. Lvova, E.L., Dremov, V.A., Aksyanova, G.A. et al. (1991) Tyurki taezhnogo Prichulym'ya. Populyatsiya $i$ etnos [Türks of the taiga Chulym region. Population and ethnos]. Tomsk: Tomsk State University.

7. Tomilov, N.A. (ed.) (1979) Katalog etnograficheskikh kollektsiy Muzeya arkheologii $i$ etnografii Sibiri Tomskogo universiteta [Catalog of Ethnographic Collections of the Museum of Archeology and Ethnography of Siberia, Tomsk University]. Vol. 1. Tomsk: Tomsk State University.

8. Lukina, N.V. \& Tomilov, N.A. (1972) Materialy po etnografii Sibiri [Materials on the Ethnography of Siberia. Tomsk: Tomsk State University. 
9. Zakharova, I.V. \& Tomilov N.A. (2007) Etnograficheskie nauchnye tsentry Zapadnoy Sibiri serediny XIX - nachala XXI veka. Omskiy etnograficheskiy tsentr [Ethnographic scientific centers of Western Siberia in the mid 19th - early 21st century. The Omsk Ethnographic Center]. Omsk: Nauka.

10. Tomilov, N.A. (2000) Tomskiy i omskiy opyt nauchnoy katalogizatsii etnograficheskikh fondov sibirskikh muzeev [Tomsk and Omsk experience of scientific cataloging of ethnographic funds of Siberian museums]. In: Chernyak, E.I. (ed.) Priob'e glazami arkheologov $i$ etnografov [The Ob region through the eyes of archaeologists and ethnographers]. Tomsk: Tomsk State University. pp. 134-139.

11. Smirnova, T.B. (2019) The Omsk School of Ethnography. Etnografiya. 4. pp. 181-194. (In Russian). DOI 10.31250/2618-8600-2019-4(6)-181-194

12. Funk, D.A. \& Tomilov, N.A. (ed.) (2006) Tyurkskie narody Sibiri [The Turkic Peoples of Siberia]. Moscow: Nauka. 